\title{
The influence of patterns of flowering of some subterranean clover (Trifolium subterruneum L.) accessions and cultivars on total seed set and autumn germination in a cool temperate environment with sporadic summer rain
}

\author{
M.L. SMETHAM, D.W. JACK and SANDY E.H. HAMMOND \\ Department of Plant Science, Lincoln University, PO Box 84, Canterbury
}

\begin{abstract}
Fifteen accessions and 3 cultivars of subterranean clover (Trifolium subterranean L.) were sown in autumn in shallow stony soil south of Christchurch, New Zealand. The following growing season was atypical, with drought occurring briefly but one month earlier than usual, the rest of the season being wetter than usual. Contrary to previous results highest seed yields were given by mid- to lateseason flowering lines. Early flowering lines were severely disadvantaged by the early drought, resulting in seed yields of only $20-25 \mathrm{~kg} / \mathrm{ha}$. High seed yields were linked with the ability of lines to recommence flowering after drought and continue this for a prolonged period. Two late flowering accessions, 014454B and 014205B, yielded more than $200 \mathrm{~kg} / \mathrm{ha}$ seed, outyielding the late flowering cv. Tallarook in spite of this cultivar having the same ability as the other two to reflower. Six highseed yielding lines gave naturally regenerated seedling numbers near to or exceeding $1000 / \mathrm{m}^{2}$. Apparent hardseededness at the time of autumn germination averaged $49 \%$ which was lower than expected for this site. It is concluded that lateflowering lines of subterranean clover should always be included in mixtures of this species for pasture to ensure adequate regeneration in wetter than normal seasons.
\end{abstract}

Keywords: accessions, cultivars, flowering, hardseededness, regeneration, seed production, Trifolium subterraneum

\section{Introduction}

The autumn, winter and early spring herbage production from subterranean clover (Trifolium subterraneum L.) swards is highly dependent on seedling density (Silsbury \& Fukai 1977). Recent studies of subterranean clover regeneration in New Zealand (Chapman et al. 1986; Smetham \& Wu Ying 1991) record low seedling densities following autumn germination. Research to increase seedling density has involved screening for increased total seed production (Smetham \& d. 1993).
In a true mediterranean environment with a sudden end to rainfall receipt such as experienced in southern Western Australia, one of the most important determinants of seed production and hence success of the annual legume subterranean clover is the time at which flowering starts relative to the onset of drought in late spring-summer. Hence Rossiter (1959) found a very strong curvilinear relationship between the number of days to first flower and seed yield.

However, unpublished work by M.L. Smetham in the 1968-69 season failed to demonstrate any such relationship for 37 named subterranean clovers grown on a shallow soil in the cool temperate climate of Canterbury, mid South Island, New Zealand. This climate is characterised by a mean annual rainfall of $650 \mathrm{~mm}$, divided approximately evenly on a monthly basis. The effectiveness of this rainfall is minimal in summer; however, variability is high and in some years summer rains are considerable. Features of subterranean clover flowering behaviour may possibly allow some ecotypes to take advantage of such variability. An indication that such features may exist is given by the findings of Francis \& Gladstones (1974) who demonstrated that cv. Seaton Park produced more seed than three other $\overline{c u}$ litivars đue to a significantly-higher rate of flower production. The investigation reported here was carried out to determine if differences in flowering pattern between ecotypes of subterranean clover do occur, and, if so, how important these are in relation to seed production and regeneration.

\section{M aterials and methods}

On 2 May 199315 numbered accessions and 3 commercial cultivars as pure swards, and one commercial cultivar in mixture with Grasslands Maru phalaris (Phalaris aquatica) (Table 2) were drilled after inoculation, into worked ground at a site $11 \mathrm{~km}$ southwest of Christchurch, New Zealand at $43^{\circ}$ 50'S. The seed was obtained originally from, the Trifolium gene bank, Department of Western Australia, Perth, Australia. The seed rate was adjusted to give 1000 germinable seeds/ $\mathrm{m}^{2}$. The soil was a shallow, stony Recent intergrade (Cutler 1957) with a $\mathrm{pH}$ of $5.7 .400 \mathrm{~kg} / \mathrm{ha}$ of $20 \%$ sulphur enriched superphosphate was broadcast on the 
experimental area a week after drilling. The experiment used a fully randomised block design, with 6 replicates, plots being $3 \mathrm{~m}$ by $1.5 \mathrm{~m}$, and seperated from each other by an unsown $1.5 \mathrm{~m}$ wide strip each way. Germinated seedlings at the cotyledon or unifoliate (true) leaf stage were counted on 22 June 1993 in one $0.1 \mathbf{~ m}^{\mathbf{2}}$ quadrat in each plot. From late August 1993 through to January 1994 plots were inspected at weekly intervals for the presence of flowers, and their relative abundance and soil moisture was estimated. Plots were not grazed until 3 January 1994, when 350 lambs grazed off surplus herbage and weeds. At this stage the production of flowers by the subterranean clovers had virtually ceased. Between 2 and 11 February 1994, plots were sampled for seed production. Seedlings resulting from natural regeneration were counted on 6 April 1994 after full autumn germination had occurred. Results were analysed for significance using Minitab V8 statistical software.

\section{Results}

Germination occurred within 5 days of sowing, and while suffering considerable bird damage during the next 10 days the populations remaining were considered to be sufficient to warrant continuation of the experiment. Regression analysis on subsequent seed production showed that the effect of these differing populations was minimal $\left(\mathrm{r}^{2}: 0.08\right)$.

\section{Climate}

Rainfall over the winter months and August was substantially below average (Table 1) whereas it was considerably higher than average in spring and summer, except for a very dry October when rainfall was less than one fifth of normal. Evapotranspiration was lower than usual during September through to the end of December due mainly to the lower mean temperatures experienced over this period (Table 1). As a result soils in August were drier than usual and while in September, November and December were much wetter than usual, the low October rainfall resulted in all plant-available moisture disappearing from the top $30 \mathrm{~cm}$ of the soil by 18 October. Regular rainfall commenced on 30 October, and thereafter soil moisture stayed above wilting point until early January when the experiment terminated.

\section{Seed production}

Table 2 lists the accessions and cultivars in the observed order of first flower appearance. In general the lines producing most seed were those flowering late rather than early, although not all late flowering lines produced high seed yields.

Significant differences occurred between subterranean clover lines for the amount of seed produced ( $P>0.05$ ). Line 014454B produced the most seed, although not significantly more than $014205 \mathrm{~B}$ or 9756 with the latter 2 lines having a similar yield to 014205A, cv. Enfield, 014555A, 014211C, and cv. Tallarook. Other lines produced considerably less, ranging from $5-70 \mathrm{~kg} / \mathrm{ha}$.

\section{Natural regeneration and hardseededness}

In general, the number of seeds germinating paralleled seed production, with minor changes in order resulting from differences in hardseededness. Accessions 014205B and 9756 had significantly more seedlings germinating in the autumn than $014211 \mathrm{C}$ or 014198 , although 014454B, 014205A, cv. Enfield and 014555A were not significantly different (Table 2). Another five lines gave seedling numbers ranging from 310 to $597 /$ $\mathrm{m}^{2}$, while the rest gave considerably fewer.

A comparison of the numbers of seeds apparently remaining ungerminated at 6 April 1994, as a percentage of the total numbers of seeds present at 11 February (Table 4), shows that out of 18 lines, 11 had between $48 \%$ and $69 \%$ of seed ungerminated in late autumn. Means failed to reach significance at $P>0.05$ because of high variability.

\section{Pattern offlowering}

The detailed notes about flowering recorded in this experiment allowed the quantification of flowering behaviour for each seedline (Table 3). The majority of the parameters were significantly correlated $(\mathrm{P}<0.01)$ with seed produced, the most important being 'Days of flowering after drought'; 'Days of recommenced

Table 1 Rainfall and evapotranspiration data recorded at Lincoln University meteorological station in 1993. (Long-term averages in parenthesis.)

\begin{tabular}{|c|c|c|c|c|c|c|c|c|c|}
\hline & April & May & June & july & A ug. & Sept. & Oct. & Nov. & Dec. \\
\hline $\begin{array}{c}\text { Rainfall } \\
(\mathrm{mm})\end{array}$ & $\begin{array}{l}7 \quad 2 \\
.(56)\end{array}$ & $\begin{array}{c}28 \\
(71)\end{array}$ & $\begin{array}{l}46 . \\
(61)\end{array}$ & $\begin{array}{c}14 \\
(68)\end{array}$ & ( 2 & $\begin{array}{r}133 \\
(47)\end{array}$ & $\begin{array}{c}9 \\
(49)\end{array}$ & $\begin{array}{c}90 \\
(53)\end{array}$ & $\begin{array}{l}119 \\
\text { (57) }\end{array}$ \\
\hline $\begin{array}{l}\text { Evapotrans- } \\
\text { piration ( } \mathrm{m} \mathrm{m} \text { ) }\end{array}$ & $\begin{array}{l}29 \\
(58)\end{array}$ & $(35)^{\prime 19 .}$ & $\begin{array}{c}14 \\
(26)\end{array}$ & $\begin{array}{c}15 \\
(29)\end{array}$ & $\begin{array}{l}23 \\
(44)\end{array}$ & $\begin{array}{c}35 \\
(62)\end{array}$ & $\begin{array}{c}52 \\
(86)\end{array}$ & $\begin{array}{c}56 \\
(105)\end{array}$ & $\begin{array}{r}65 \\
(114)\end{array}$ \\
\hline
\end{tabular}


Table 2 Flowering, seed production, natural regeneration and hardseededness of subterranean clover accessions and cultivars in Canterbury, New Zealand.

\begin{tabular}{|c|c|c|c|c|c|}
\hline $\begin{array}{l}\text { Accessions \& } \\
\text { Cultivar }\end{array}$ & $\begin{array}{l}\text { Days to first flower } \\
\text { appearance from } \\
30 \text { August }\end{array}$ & $\begin{array}{c}\text { Seed Production } \\
\mathrm{kg} / \mathrm{ha} \mathrm{a}^{*}\end{array}$ & $\begin{array}{l}\text { Days of recovered } \\
\text { flowering after drought }\end{array}$ & $\begin{array}{l}\text {-Numbers of } \\
\text { seedlings } / \mathrm{m}^{2} t\end{array}$ & $\begin{array}{l}\text { Hardseed } \\
\quad \% \#\end{array}$ \\
\hline $\begin{array}{l}015077 \\
\text { Dalkeith } \\
0152580 \\
\text { Dalkeith } \\
+ \text { Maru }\end{array}$ & $\begin{array}{l}9 d \\
15 d \\
22 c d \\
25 c d\end{array}$ & $\begin{array}{l}26.2 \mathrm{~cd} \\
27.0 \mathrm{~d} \\
20.7 \mathrm{~cd} \\
25.4 \mathrm{~d}\end{array}$ & $\begin{array}{l}1 \mathrm{C} \\
0 \mathrm{C} \\
\mathrm{OC} \\
\mathrm{OC}\end{array}$ & $\begin{array}{l}196 \mathrm{~cd} \\
113 \mathrm{~cd} \\
186 \mathrm{~cd} \\
154 \mathrm{~cd}\end{array}$ & $\begin{array}{l}59 \\
68 \\
67 \\
69\end{array}$ \\
\hline $\begin{array}{l}015258 \mathrm{C} \\
012683 \\
\text { Enfield } \\
0142118 \\
014205 \mathrm{~A}\end{array}$ & $\begin{array}{l}29 c \\
32 c \\
35 b c \\
36 b c \\
37 b c\end{array}$ & $\begin{array}{c}13.4 \mathrm{~d} \\
5.4 \mathrm{~d} \\
99.2 \mathrm{bc} \\
68.1 \mathrm{c} \\
134.3 \mathrm{~b}\end{array}$ & $\begin{array}{r}5 c \\
0 c \\
11 c \\
7 c \\
27 b\end{array}$ & $\begin{array}{l}251 \mathrm{~cd} \\
90 \mathrm{~cd} \\
953 \mathrm{ab} \\
597 \mathrm{bc} \\
1635 \mathrm{ab}\end{array}$ & $\begin{array}{l}38 \\
27 \\
48 \\
48 \\
35\end{array}$ \\
\hline $\begin{array}{l}9756 \\
01421 \quad 1 A\end{array}$ & $\begin{array}{l}37 b c \\
39 b c\end{array}$ & $\begin{array}{c}184.7 \mathrm{ab} \\
70.7 \mathrm{c}\end{array}$ & $\begin{array}{r}28 b \\
6 \mathrm{c}\end{array}$ & $\begin{array}{r}1859 \mathrm{a} \\
515 \mathrm{bc}\end{array}$ & $\begin{array}{l}36 \\
43\end{array}$ \\
\hline $\begin{array}{l}014326 \mathrm{H} \\
014555 \mathrm{~A} \\
014198\end{array}$ & $\begin{array}{l}40 \mathrm{bc} \\
40 \mathrm{bc} \\
40 \mathrm{bc}\end{array}$ & $\begin{array}{l}42.5 \mathrm{~cd} \\
97.4 \mathrm{bc} \\
34.9 \mathrm{~cd}\end{array}$ & $\begin{array}{l}0 \mathrm{c} \\
26 \mathrm{~b} \\
17 \mathrm{bc}\end{array}$ & $\begin{array}{l}494 \text { bc } \\
943 \text { ab } \\
669 \text { b }\end{array}$ & $\begin{array}{l}48 \\
51\end{array}$ \\
\hline $\begin{array}{l}012722 \\
01421 \text { iC }\end{array}$ & $\begin{array}{l}43 b c \\
44 b\end{array}$ & $\begin{array}{l}11.2 \mathrm{~d} \\
96.2 \mathrm{bc}\end{array}$ & $\begin{array}{l}1 \mathrm{c} \\
28 \mathrm{~b}\end{array}$ & $\begin{array}{l}310 \mathrm{bc} \\
686 \mathrm{~b}\end{array}$ & $\begin{array}{l}40 \\
53\end{array}$ \\
\hline 0144548 & $46 \mathrm{ab}$ & $271.3 \mathrm{a}$ & $34 a b$ & $1646 a b$ & 57 \\
\hline Tallarook & $49 a b$ & 93.7 bc & $36 a b$ & $557 b c$ & 59 \\
\hline 0142058 & $56 a$ & $216.1 \mathrm{ab}$ & $43 a$ & 1928 a & 34 \\
\hline
\end{tabular}

Means without a letter in common differ significantly.

LSD calculated from $t=95 \mathrm{df}$ and $\mathrm{p}=0.05$.

- Data back transformed after statistical analysis of square root-transformed data.

t Data back transformed after statistical analysis of log-transformed data.

\# Means were not significantly different.

- Missina data.

flowering after drought'; and 'Total number of days of flowering' with these accounting for $46 \%, 42 \%$ and - $33 \%$ of the variation in seed yield respectively. 'Days of flowering after drought'-and-'Days-of-recommenced flowering after drought' were themselves very strongly correlated ( $r=0.93$ ). A comparison of seed production with 'Days of recommenced flowering after drought' in Table 2 demonstrates, with the exception of cv. Enfield, the coincidence of high seed yield with high numbers of days of such flowering. Table 3 shows the close correlation $(r=0.73)$ obtained between numbers of seedlings on 6 April 1994 and the amount of seed produced; however, that between apparent hardseededness and seed production was weak and negative.

\section{Discussion}

\section{Seed production and flowering behaviour}

The major agricultural attributes of subterranean clover are its persistence and cool-season production in low rainfall areas. These require the successful establishment of a high seedling density (Silsbury \& Fukai 1977) every year and the use of cultivars with high reseeding ability and/or low hard seed content. The high levels of hardseededness usually experienced with subterranean
Table 3 Estimates of correlation between aspects of the flowering pattern of subterranean clover and subsequent seed production in 1993.

\begin{tabular}{lc}
\hline Parameter & Correlation \\
\cline { 2 - 3 } & coefficient- \\
\hline Days to first flower appearance, from 30 August & 0.443 \\
Days of flowering before drought & -0.425 \\
Days of flowering after drought & 0.677 \\
Days of maximum flowering before drought & -0.330 \\
Days of maximum flowering after drougtht & 0.402 \\
Days of recommenced flowering after drought & 0.649 \\
Days (total) of flowering & 0.576 \\
Days (total) of maximum flowering & $0.143 \mathrm{~ns}$ \\
Hardseed percentage & $-0.033 \mathrm{~ns}$ \\
Numbers of seedlings, 22 June 1993 & 0.283. \\
Numbers of seedlings, 6 April 1994 & $0.731 . *$ \\
\hline
\end{tabular}

At-112 df, $r=0.185$ for $P<0.05 ; r=0.241$ for $P<0.01$

clover in the New Zealand environment (Smetham \& Wu Ying 1991; Smetham et al. 1993) mean that high seed production is important for the agricultural success of this clover since it helps to ensure that enough seed germinates in the autumn to give a high seedling density.

In the results reported here, highest seed yields came from late-flowering,lines, quite unlike the 1985- 
90 results for the same area reported by Smetham $\boldsymbol{e t}$ al. (1993) which indicated that early flowering ecotypes set more seed than late. However, the climatic conditions in 1993 appear to have been atypical. The onset of drought a month earlier than usual appeared to disadvantage the early flowering lines like 015077 , 015258B and cv. Dalkeith which had died off by the onset of drought. The number of days of flowering before the drought of mid October was negatively correlated with seed yield (Table 3 ) because lines flowering early, and well before drought, failed to mature much seed, whereas some lines commencing flowering just before the drought were able to survive to flower or recommence flowering as moisture improved. Some of these were therefore able to mature more seed because of regular rains thereafter. The three characteristics of the flowering pattern most closely linked with seed production 'days of flowering after drought', 'days of recommenced flowering after drought', and 'days total of flowering' were all strongly dependent on days of flowering and may therefore have been measuring the same attribute. This is supported by the fact that the first two explained a similar portion of the variance in seed yield, and were strongly correlated with each other. The ability to recommence flowering (or 'kick-on') after near death may be the reason for the relatively greater success of cv. Tallarook compared with other cultivars in a variety of environments throughout New Zealand (Chapman $\boldsymbol{e t}$ al. 1986). Although in the results reported here cv. Tallarook exhibited a high number of days of recommenced flowering, resultant seed yield was not nearly as high as some accessions with similar ability to 'kick-on'. Such ability has not been reported for subterranean clover before.

Other aspects of the flowering patterns reported here, e.g. 'days of maximum flowering after drought' were not as strongly correlated with seed production but may have explained a small part of the variance. There are undoubtedly other aspects of flowering which may influence seed production, for instance the rate of production of flowers found by Francis \& Gladstones (1974) to explain superior seed production by cv. Seaton Park.

\section{Level of seed production and regeneration}

Calculations allowing for the loss of seed from 'false breaks', consumption of burr by animals grazing, innate varietal hardseededness, and the need to obtain at least 1000 seedlings $/ \mathrm{m}^{2}$ for a pure stand of subterranean clover (Smetham \& Dear in press) show that to be agriculturally successful the seed yield of a cultivar must lie between 200 and $250 \mathrm{~kg} / \mathrm{ha}$. Two accessions only out of the eighteen lines tested achieved such production, and both were late flowering with the ability to 'kick-on'. Cv. Tallarook was late flowering, and recommenced flowering well but lacked the ability to yield well.

Taylor et al. (1984) suggests that to be agriculturally successful a subterranean clover needs to give a minimum of 1000 seedlings $/ \mathrm{m}^{2}$ at germination in the autumn, Five accessions and one cultivar- 'Enfield approached or exceeded this threshold. The strong correlation between seedling numbers and seed yield indicates that one way of achieving high numbers is to select lines with high seed yield. This is particularly so in New Zealand, and cooler areas of Australia and Tasmania where the climate is such that hardseededness is lost only slowly (Smetham \& Wu Ying 1991) with the result that $50 \%$ or more of seed formed in any one year does not germinate that autumn. In the present investigation moderately high levels of hard seed were still evident at the time of autumn germination in all lines, although the mean level of hardseededness (49\%) was not as high as that measured by Smetham $\boldsymbol{e t}$ al. (1993) at a nearby location in 1991. Such hardseed developement occurs as a result of seed maturation under good moisture, followed by a period allowing drying (Quinlivan \& Millington 1962). In the 1993 season it is possible that the cooler moister conditions in the 1993 season did not allow the full expression of this character.

\section{Conclusion}

In environments where subterranean clover is a highproducing pasture legume worth growing, seed mixtures should contain late flowering lines with the ability to reflower after drought. This will maximise regeneration in seasons with better than normal moisture.

\section{REFERENCES}

Chapman, D.F.; Sheath, G.W.; Macfarlane, M.J.; Rumball, P.J.; Cooper, B.M.; Crouchley, G.; Hoglund, J.H.;Widdup, K.C. 1986. Performance of subterranean and white clover varieties in dry hill country. Proceedings of the New Zealand Grassland Association 48: 53-62.

Francis, C.M.; Gladstones, J.S. 1974. Relationships among rate and duration of flowering and seed yield components in subterranean clover (Trifolium subterraneum L.). Australian journal of agricultural research 25: 435-442.

Quinlivan, B.J.; Millington, A.J. 1962. The effect of a Mediterranean summer environment on the permiability of hard seeds of subterranean clover. Australian journal of agricultural research 13: 377. 387. 
Rossiter, R.C. 1959. The influence of maturity grading on total yield and seed production of Trifolium subterraneum L. grown as single plants or in swards. Australian journal of agricultural research 10:305321.

Silsbury, J.H.; Fukai, S. 1977. Effects of sowing time and sowing density on growth of subterranean clover at Adelaide. Australian journal of agricultural research 28: 427-440.

Smetham, M.L.; Wu Ying, C.C.K. 1991. Establishment of subterranean clover (Trifolium subterraneum L.) in New Zealand 1. Hardseededness and autumn germination. New Zealand journal of agricultural research 34: 3 1-44.

Smetham, M.L.; Hines, S.; Jack, D.W. 1993. Seed production and autumn germination as determinants of the success of subterranean clover in a cool temperate environment. Proceedings of the XVII International Grassland Congress: 307-309.

Taylor, G.B.; Rossiter, R.C.; Palmer, M.J. 1984. Long term patterns of seed softening and seedling establishment from single seed crops of subterranean clover. Australian journal of experimental agriculture 24: 200-212. 